\title{
EFFECTIVENESS OF PIANO VIRTUAL MEDIA ON THE PGSD STUDENTS RETENTION IN BASIC PIANO THEORY
}

\author{
Rudi Akmal $^{1}$, Ani Yanti Ginanjar ${ }^{2}$, Euis Shintawati ${ }^{3}$ \\ ${ }^{1}$ Primary teacher Education, FPIK, Garut University \\ ${ }^{2}$ Primary teacher Education, FPIK, Garut University \\ ${ }^{3}$ SDN 036 Ujungberung, Department of Education Bandung \\ 1'rudiakmal@uniga.ac.id, ${ }^{2}$ aniyanti21@gmail.com, ${ }^{3}$ shintawati24@gmail.com
}

\begin{abstract}
This study was conducted to determine the effectiveness of virtual piano media on PGSD students' memory on scale material. This study used a quasi-experimental one-group pretest-posttest design method. This study did not use a comparison class but already used a preliminary test so that the effectiveness of virtual piano media can be ascertained with certainty. In this study, the research subjects were first given a pretest to determine the extent of students' understanding before being given treatment using virtual piano media. The subjects in this study were 35 students. This research uses to test and non-test instruments. The non-test form includes distributing questionnaires. The data analysis technique used a parametric test for N-gain improvement and Paired Samples Test SPSS Version 25. The results proved that there was a significant difference between the pretest score and the posttest score after treatment with a 2-tailed sign value of $0.000 \leq 0.05$. Then there is a significant increase in the memory of students who use learning with virtual piano media rather than direct learning. It can be seen that learning with Virtual Piano Media provides a significant increase with an average N-gain of 0.72 and is included in the high category.
\end{abstract}

Keywords: basic piano theory, memory, scale, virtual piano media.

\begin{abstract}
Abstrak
Penelitian ini dilakukan untuk mengetahui efektivitas media virtual piano terhadap daya ingat mahasiswa PGSD pada materi tangga nada. Penelitian ini menggunakan metode kuasi eksperimen one group pretest-posttest design. Penelitian ini tidak menggunakan kelas pembanding namun sudah menggunakan tes awal sehingga besarnya efektivitas media virtual piano dapat diketahui secara pasti. Dalam penelitian ini, subyek penelitian terlebih dahulu diberikan tes awal (pretest) untuk mengetahui sejauh mana pemahaman mahasiswa sebelum diberikan perlakuan dengan menggunakan media virtual piano. Subjek pada penelitian ini sebanyak 35 mahasiswa. Penelitian ini menggunakan instrumen tes dan nontes. Adapun bentuk nontes dengan penyebaran angket. Teknik analisis data dengan menggunakan tes parametik peningkatan N-gain dan Paired Samples Test SPSS Versi 25. Hasil penelitian membuktikan bahwa terdapat perbedaan yang signifikan antara skor pretes dengan skor postes setelah perlakuan dengan nilai sign 2 -tailed $0,000 \leq 0,05$. Kemudian terdapat peningkatan yang signifikan terhadap daya ingat mahasiswa yang menggunakan pembelajaran dengan media virtual piano daripada pembelajaran langsung. terlihat bahwa pembelajaran dengan Media Virtual piano memberikan peningkatan yang signifikan dengan rataan $\mathrm{N}$-gain sebesar 0,72 dan masuk pada kategori tinggi.
\end{abstract}

Kata Kunci: teori dasar piano, daya ingat, tangga nada, media piano virtual

\section{INTRODUCTION}

In the 21st century, technology and communication have developed very rapidly, including smartphone technology (Husain, 2014). Smartphones have various operating systems and one that is in demand today is android. Android is an operating system based on open source (Maiyana, 2018). Android which is open source makes it easy for users to create and install applications on a smartphone. This can be used in the field of education, especially to 
develop learning media that can be installed on smartphones with the Android operating system. The learning media in this smartphone is more interesting because it can contain learning material with additional images, sounds, or animations. The use of media in the learning process is an effort to create more meaningful and quality learning.

Learning media serves as a tool to convey learning messages in the hope that after carrying out the learning students will have a strong understanding and memory. This is one aspect of the cognitive realm. According to (Syafrina \& Farhan, 2016), One of the efforts to improve the learning process is the use of media effectively to enhance the quality of learning. Memory is something that forms human identity and differentiates humans from other living things. Furthermore, according to (Suparmi, 2010) memory is the basic foundation for human psychological activities. With this memory, the human mind's life becomes rich with shadows and descriptions of everything it observes, whether everyday events, objects, or events in the past. According to (Sari \& Grashinta, 2015) Memory is a psychic ability to receive, store, and bring back stimuli or events that someone has experienced. It can be concluded that memory is one of the cognitive functions that play a lot in the process of thinking, problem-solving, and intelligence (intelligence). Almost all human behavior is influenced by memory.

One application that can be used as a learning medium that can be used in scale material is the virtual piano application. Virtual Piano is an imitation musical instrument that is an application or software on Android and can be played with your fingers by pressing keys starting from the lowest note located on the left in sequence to the highest note on the right. As one of the most popular musical instruments, according to research conducted by (Wiraguna et al., 2014), several obstacles become obstacles because the piano is not as practical as other musical instruments. The piano is so large that it is very difficult to carry. Usually, the piano is only kept at home and played at home. Musicians usually only take the piano out to play at certain events. Besides, according to (Fadhilah et al., 2016), many people are hampered in learning this instrument because the price of the piano is quite expensive. If someone takes piano lessons, it will hinder their learning. But if you have a personal musical instrument, you will be able to master the instrument faster because you can keep repeating the material. According to (Wiraguna et al., 2014) if a musical instrument is made virtual it will be very helpful and answer problems as described above. Therefore, a virtual application of a piano musical instrument is made that implements the musical tone into the application system according to the notes on the actual musical instrument. So that in addition to being practical and can be carried everywhere, a virtual piano can make it easier for students to learn and 
remember the theory of scales, can be used as an alternative musical instrument, and become a learning medium in school or college. In line with (Rahmawati \& Lakoro, 2017) research, in learning so that one's memorization and memorization power becomes strong in learning musical instruments, it is necessary to have learning media accompanied by the sound of instruments.

Learning the art of music, especially the piano, the basic theory that must first be learned is memorizing and practicing scale fingering. Allen Winold in (Wajongkere et al., 2019) argues that the tones as part of the scale are sounds that have high and low levels, which are regular and standardized vibrations. Currently used in the international tone system there are 12 standardized main tones, namely C, C \#, D, D \#, E, F, F \#, G, G \#, A, A \#, and B, These notes can be arranged into a ladder. tone by specifying a note as a tonic and entering the scale-forming intervals. The scales that are widely known and used internationally are the major and minor diatonic scales. In this study, it focuses on 7 major diatonic scales, namely: C, D, E, F, G, A, and $\mathrm{B}$.

In connection with the above problems, the researchers are interested in testing how effective virtual piano learning media is on PGSD student memory on scale material. As stated by (Wiraguna et al., 2014) who reveals that if a musical instrument is made virtual it will be very helpful and answer problems such as difficulty understanding basic tones. The importance of this study is to provide an idea whether the memory of students who use virtual piano media in learning scales can increased. Likewise in schools or colleges that do not have good facilities, especially in the learning process. There are other alternatives by taking advantage of existing technological advances, and which are easier to implemen

\section{METHOD}

This study did not use a comparison class but already used a preliminary test so that the effectiveness of virtual piano media can be ascertained with certainty. In this study, research subjects were first given a pretest to determine the extent to which students' memory abilities were given before being treated using virtual piano media. After being given the initial test, then the student was given treatment, using virtual piano media. Then students are given a final test (posttest) to determine the extent of the effectiveness of the virtual piano media against the memory of basic piano theory or scales.

The type of design used is Experiment with one group pretest and posttest design. According to (Sugiyono, 2012) one group pretest and posttest design is a technique to 
determine the effects before and after treatment. The data obtained are quantitative data and qualitative data, in the form of test results of students' memory skills on the basic theory of piano on the scale material. Then for qualitative data using the non-test, the researcher distributed questionnaire responses to students about the effectiveness of virtual piano media on scale material. From the data obtained, this study is continued by analyzing the data and then concluding using parametric statistics. Tests carried out with the normality test using the Kolmogorov-Smirnov test with the help of SPSS version 25. The hypotheses in this study include $\mathrm{H}_{0}$ : there is no positive and significant effect of the effectiveness of Virtual Piano media on the understanding and memory of Pgsd Students in Theory Piano Basics and $\mathrm{H}_{1}$ : there is a positive and significant effect on the effectiveness of Virtual Piano media on the understanding and memory of Pgsd students on theory basic piano.

The results of normality were then tested with the homogeneity test, but in this study, it was certainly homogeneous because the test was carried out on one sample. Then the t-test was carried out which was used to determine the effect of the treatment used. Hypothesis testing uses the t-test with the help of the SPSS 25 program. The t-test is a test using the $t$ distribution on the significance of differences in certain mean values of two unrelated sample groups. The case study used the paired sample T-test. According to (Singgih, 2014) paired sample T-test is a test conducted on two paired samples. Paired samples can be defined as samples with the same subject but undergoing two different treatments. Testing to determine whether there is an increase in using the $\mathrm{N}$-gain test.

\section{RESULTS AND DISCUSSION}

\section{Results}

Based on the results of data analysis from statistical data processing in the form of pretest, posttest, and $\mathrm{N}$-gain scores. The following is a description of the pretest, posttest, and $\mathrm{N}$-gain data in the control and experimental groups.

Table 1. Descriptive Statistics of Memory Pretest and Posttest

\begin{tabular}{lccclll}
\multirow{2}{*}{ Class } & \multicolumn{4}{c}{ Kolmogorov-Smirnov } & \multirow{2}{*}{ Conclusion } & \multicolumn{2}{l}{ Information } \\
\cline { 2 - 5 } & Statistik & Df & Sig. & & \\
\hline \multirow{2}{*}{ Eksperiment } & .269 & 35 & .001 & Ho rejected & \multirow{2}{*}{ Not normally distributed } \\
\hline Eksperiment & .163 & 35 & .045 & Ho rejected & Not normally distributed
\end{tabular}


Based on Table 1, it can be seen that the significance value of the pretest data test results for the experimental class students' memory score is $0.001<\alpha=0.05$ so it can be concluded that Ho is rejected, meaning that the pretest score data for the experimental class is not normally distributed. Then the results of the post-test data test results of students' memory in the experimental class were $0.045<\alpha=0.05$, so it can be concluded that Ho was rejected, meaning that the pretest score data for the experimental class was not normally distributed. So it can be concluded that the pretest and posttest score data are not normally distributed. Because the sample used is one, it does not need to be tested for homogeneity. For this reason, the next test to determine whether or not there is a change in the experimental class is used the Paired Samples Test.

Table 2. Result of Paired Samples Test Score of Pretest Posttest Retention

\begin{tabular}{cll}
\hline & Pretest-Postest & Information \\
\hline $\begin{array}{c}\text { Paired Samples Test } \\
\text { (Sign 2-Tailed) }\end{array}$ & 0,000 & - \\
\hline
\end{tabular}

Note that the value of Sig. 2-tailed $0.000 \leq 0.05$. Therefore, the statistically significant test results reject Ho. This means that there is a significant difference between the average pretest memory score of the experimental class and the post-test score before being given the action.

Table 3. Results of Mean and N-gain classification Retention

\begin{tabular}{lll}
\hline Group & N-gain Mean & Classification \\
\hline Experiment & 0,72 & High \\
\hline
\end{tabular}

In Table 3 above, it can be seen that learning with Virtual Piano Media provides a significant increase with an average $\mathrm{N}$-gain of 0.72 and is included in the high category. Then the changes that occur in the experimental class after being given action have a significant effect on student memory.

\section{Discussion}

The memory skills that students must have in the material of scales in this study are that students must be able to generate or recall information that has been explained during learning, by practicing or playing 7 scales. in measuring the assessment of this memory test using a rubric with the following criteria: high, medium, and low. 


\begin{tabular}{|c|c|c|c|}
\hline Variable & $\begin{array}{c}\text { Description } \\
\end{array}$ & Score & Criteria \\
\hline \multirow{3}{*}{ Memory } & $\begin{array}{l}\text { If students can Plays a } 6-7 \text { chord } \\
\text { scale correctly using the Virtual } \\
\text { Piano }\end{array}$ & 3 & High \\
\hline & $\begin{array}{l}\text { If students can Plays a } 3-5 \text { chord } \\
\text { scale correctly using the Virtual } \\
\text { Piano }\end{array}$ & 2 & Middle \\
\hline & $\begin{array}{l}\text { If students can Plays a } 1-2 \text { chord } \\
\text { scale correctly using the Virtual } \\
\text { Piano }\end{array}$ & 1 & Low \\
\hline
\end{tabular}

Figure 1. Student memory assessment rubric

Therefore, to create learning that is expected to improve student memory, learning alternatives that can be used by using virtual media. According to research by (Kaledasa, 2016), which states that memory must improve students themselves not only at school but also at home regularly and gradually to get maximum results. For this reason, in learning scales students are required to practice regularly and get used to playing a piano instrument in the learning stage to remember the material scales well. (Dharmawan, 2016) explains that memory starts from short-term memory which is then repeated to remember all the information that can be. So, it becomes a long term memory. (Widyarsi, 2018) describes the stages in memory.

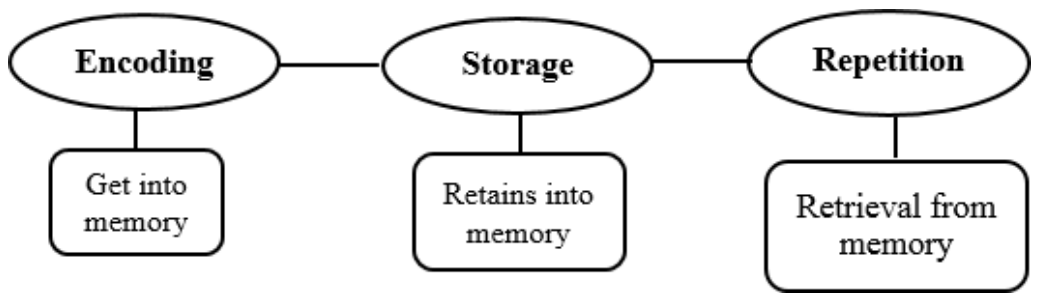

Figure 2. Stages of memory

The picture above explains that there are three stages of remembering, starting from entering information (learning), storing (retention), and recalling (remembering). This process is not independent or isolated, but interrelated and dependent on one another. (Suhadianto, 2016) explains that memory is an element of cognitive development, which contains all situations in which individuals store information received at all times. In research (Julianto, 2017) Memory refers to an individual's ability to have and retrieve information as well as the structures that support it and a form of competence, memory also allows individuals to have their personality. The importance of memory as a mental function that captures information from stimuli, and it is a storage system, namely a storage system for information and knowledge contained in the human brain. Here, memory is the working system of the human brain to 
capture and store knowledge. Tulving reveals that memory is how individuals can retain and draw experiences from the past to be used today (King, 2014). Meanwhile, (Amrizal, 2014) explains that memory is the ability to remember what is already known.

A person's memory can be improved by various factors. One of them is by increasing effective learning. Therefore, the use of learning media can make it easier and help students convey information or bring back experiences, symbols, images that will be reappeared with consideration of their situation and condition. In the use of this media, students are treated as learning subjects where learning is emphasized on student activities (student-centered).

The improvement of students' memory was obtained from the pretest and posttest score data. Then, the two scores were determined by the N-gain score data. This N-gain data is then analyzed to determine whether the increase that occurs is better than before being given treatment in the experimental class. The average memory improvement or N-gain in the experimental class was 0.72 . The criteria for improving the memory of students who take lessons using virtual media are high. The classification of the $\mathrm{N}$-gain level after treatment underwent a change, where the experimental class had a higher $\mathrm{N}$-gain after treatment.

Learning with virtual piano media has a higher impact on improving student memory. The experimental class after treatment is better than before treatment because when students learn by learning using virtual media, the students are easier to remember the basic notes that can be heard and practiced immediately, students can understand and remember the functions of the seven main tones plus the five insert tones, scales These are called diatonic scales which can help when you want to make music or music arrangements. With this application, it can support piano learning activities such as increasing tone sensitivity, both theoretically and practically. Like the results of (Melian \& Hermawan, 2014) research study which revealed that if a musical instrument is made virtual it will be very practical and can provide convenience in learning music because it is not limited by time and place.

Improving the memory of students who get learning with virtual piano media shows that by getting students to learn by remembering what was learned first and then practicing what they understand and remember, it will be easier to practice the scale material. In line with research conducted by (Wiraguna et al., 2014) that virtual musical instruments will be very helpful and answer problems such as difficulty understanding and remembering basic tones. For this reason, with virtual media, the piano facilitates learning activities to make it easier for students to understand the functions of the scales and can immediately practice them. As stated in research (Lesmideyarti et al., 2018) virtual media can improve understanding, memory, and 
make it easier to learn the basic theory of music. Reasoning ability in music is an element that supports students' ability to play a musical instrument because in playing a musical instrument, students need to link concepts with reasoning activities and present ideas through practice in playing musical instruments.

This virtual media has been designed so that it fits the learning objectives. Then the effectiveness of this virtual piano media can be felt by students when operating, so that students can understand abstract and concrete things, and can increase motivation to learn because the media display is like real objects so that it can help in understanding concepts correctly or can relate concepts to reality (contextual). So that in practice or practice it can generate new desires and interests which are used in providing a meaningful learning experience. The virtual piano can be accessed and downloaded via the App Play store application on a smartphone or Android, by searching for the keyword Real Piano. When using a virtual piano, many things need to be considered when playing in a classroom, so that the sound produced by this virtual piano media can be heard properly, then additional tools are needed in the form of active speakers that are connected to each communication device. So that the sound that is issued is maximized and feels really like the original musical instrument. The following is an example of an image from the virtual piano android media screen used in this study:

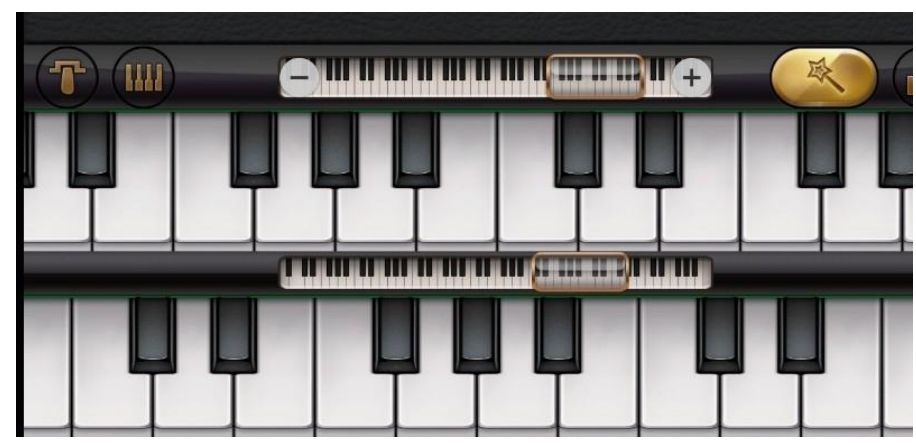

Figure 3. Virtual piano

Based on the results of the memory test on the scale material using virtual piano media, the average student memorized $\mathrm{C}, \mathrm{G}$, and A notes faster. Because the notation fingering was easier and pressed a lot of white keys. It's different from the scales D, E, F, and B. The difficulty with this notation is that it puts more emphasis on black keynotes. In this case, habituation is needed so that the fingers are weaker and not stiff. Unless some students have more interest and can play a musical instrument at an earlier level, they will be quicker to remember scales and adjust their hand fingers. 


\section{CONCLUSION}

Based on the results of research and discussion of improving the memory of students who use virtual piano media, it is higher than students before using virtual piano media. This is because by using virtual piano media, students get used to learning by understanding first then remembering and practicing what they understand and remember. The effectiveness level of virtual piano media is very high, this can be seen from the results of student questionnaires. The statement that has been chosen is that the virtual piano media is very suitable for learning objectives, the virtual piano media is easier to operate, is able to understand abstract and concrete things, the media display is like real objects and can be played like the original object, besides the virtual piano media used can help in understanding the concept properly. So that the level of effectiveness of virtual piano media on student memory is very high.

\section{ACKNOWLEDGMENTS}

Alhamdulillahi rabil 'alamin, the researcher conveyed the highest gratitude of Allah Subhanahu wa ta'ala for his blessings, love, health, and mercy even though the situation is currently in a pandemic like this. Effectiveness Of Piano Virtual Media On The PGSD Students Retention In Basic Piano Theory This research is a type of lecturer research funded by the Ministry of Research, Technology, and Higher Education, with the name genius research, namely novice researchers.

In compiling this research, many parties have provided motivation, input, and support for researchers. In this valuable opportunity, researchers would like to thank and appreciate all of them. First, the deepest appreciation of researchers given to our family who always support all of our activities. The researcher expressed his great appreciation to Mrs. Maryati Puspitasari, M.P as the Chairperson of the Garut University Research Institute for allowing us to research novice lecturers' research, besides that we also thank the Chancellor of the University of Garut Dr. Ir. H. Abdusy Syakur Amin, M.Eng, and the Dean of the Faculty of Islamic Education and Teacher Training, University of Garut Dr. Hj. Hilda Ainissyifa, M.Ag for the motivation, advice, guidance, and opportunities that have been given to us to carry out this research.

\section{REFERENCES}

Amrizal. (2014). Peranan Musik Klasik Dan Musik Pop Dalam Pembelajaran. Jurnal Pengabdian Kepada Masyarakat.

Dharmawan, T. (2016). Musik klasik dan daya ingat jangka pendek pada remaja. Jurnal Ilmiah Psikologi Terapan, 3(2), 370-382. 
Journal of Elementary Education

Volume 4, Number 2, September 2020
P-ISSN: 2580-9326

E-ISSN: 2580-7714

Fadhilah, R. F., Suciati, N., \& Khotimah, W. N. (2016). Rancang Bangun Aplikasi Piano Virtual Menggunakan Teknologi Augmented Reality dan Vuforia SDK. Jurnal Teknik ITS, 5(2), A359-A363.

Husain, C. (2014). Pemanfaatan teknologi informasi dan komunikasi dalam pembelajaran di SMA Muhammadiyah Tarakan. Jurnal Kebijakan Dan Pengembangan Pendidikan, 2(2).

Julianto, V. (2017). Meningkatkan memori jangka pendek dengan karawitan. Indigenous: Jurnal Ilmiah Psikologi, 2(2).

Kaledasa, R. P. A. (2016). Model 3 In 1 Pada Pembelajaran Piano Bagi Siswa TingkatPemula Di Sekolah Musik Indonesia Yogyakarta. Institut Seni Indonesia Yogyakarta.

King, L. A. (2014). Psikologi umum: sebuah pandangan apresiatif (terjemahan). Jakarta: Salemba Humanika.

Lesmideyarti, D., Sarimuddin, S., \& Supria, S. (2018). Virtual Musik Gamelan Dengan Menggunakan Sensor Kinect. INOVTEK Polbeng-Seri Informatika, 3(1), 9-15.

Maiyana, E. (2018). Pemanfaatan Android Dalam Perancangan Aplikasi Kumpulan Doa. Jurnal Sains Dan Informatika: Research of Science and Informatic, 4(1), 54-65.

Melian, L., \& Hermawan, H. (2014). Aplikasi Mobile Piano, Gitar, dan Drum Virtual Berbasis Android (Studi Kasus: Purwacaraka Music Studio). JATI-Jurnal Teknologi Dan Informasi UNIKOM, 1(4).

Rahmawati, L., \& Lakoro, R. (2017). Perancangan Media Digital Interaktif Gamelan Jawa Timuran sebagai Wadah Pengenalan Alat Musik Tradisional untuk Anak Usia 9-10 Tahun. Jurnal Sains Dan Seni ITS, 6(1), F74-F79.

Sari, A. P., \& Grashinta, A. (2015). Pengaruh jenis musik terhadap performa kognitif yang menuntut ingatan jangka pendek pada anak-anak usia 7-11 tahun. Jurnal Psikologi Ulayat: Indonesian Journal of Indigenous Psychology, 2(2), 450-460.

Singgih, S. (2014). Statistik Multivariat Edisi Revisi Konsep dan Aplikasi dengan SPSS. Jakarta: PT Elex Media Komputindo.

Sugiyono, S. (2012). Metode penelitian kuantitatif kualitatif dan $\mathrm{r} \& \mathrm{~b}$. bandung. Indonesia: Alfabeta.

Suhadianto, S. (2016). Pengaruh Musik Mozart terhadap Memori pada Pelajaran Menghafal di SMP Taâ $€^{\mathrm{TM}}$ miriyah Surabaya. Persona: Jurnal Psikologi Indonesia, 5(02).

Suparmi, S. (2010). Studi Meta Analisa: Strategi Rehearsal Dan Memori Jangka Pendek. Jurnal Psikologi Tabularasa, 5(2).

Syafrina, A., \& Farhan, A. (2016). Efektifitas Media Animasi Dalam Pencapaian Nilai Kriteria Ketuntasan Minimal. Jurnal Pesona Dasar, 2(4).

Wajongkere, Y., Titaley, J., \& Langi, Y. A. R. (2019). Fungsi Transposisi Modulo dan Penerapannya Pada Pencarian Susunan Tangga Nada dan Tingkatan Akor. D'CARTESIAN, 8(1), 11-17.

Widyarsi, A. H. (2018). PENGARUH BERMAIN MUSIK TERHADAP KEMAMPUAN MENGINGAT ANAK USIA 3-4 TAHUN (Penelitian Eksperimen di Playgroup Sakinah Rawamangun). UNIVERSITAS NEGERI JAKARTA.

Wiraguna, J., Trisnadoli, A., \& Dewi, M. (2014). Virtual Alat Musik Keyboard 3D. Proceeding Applied Business and Engineering Conference, 87-92. 